\title{
Variation in Productivity and Energy Use in Rice-Wheat System under Different Establishment Methods
}

\author{
Shweta*, Manu Malik, S.K. Saini and A.K. Bhardwaj \\ Department of Agronomy, CCS Haryana Agriculture University, Hisar \\ *Corresponding author
}

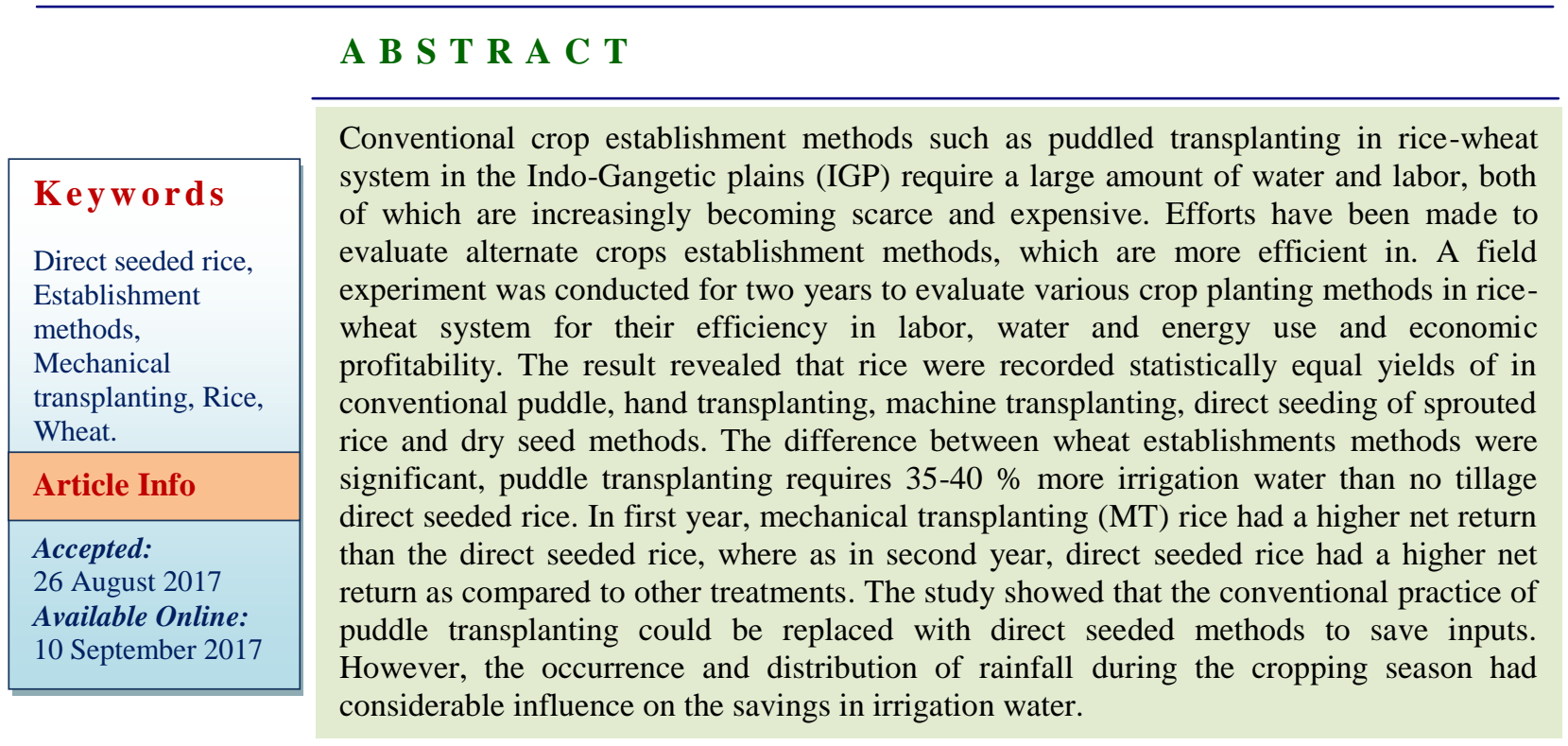

\section{Introduction}

The rice-wheat rotation is one of the major agricultural production cropping patterns in Asia. The Indo-Gangetic Plain (IGP) occupying 13.5 million ha area under ricewheat systems (Ladha et al., 2000; Dawe et al., 2004). The intensively cultivated irrigated rice-wheat system is elementary to employment, revenue and occupation for hundreds of millions of people of South Asia. The annual increase in growth rates for food grain production (wheat $3 \%$, rice $2.3 \%$ ) in the IGP have kept pace with population growth, but proof is now come into view that ricewheat cropping system productivity is plate awing because of a fatigued natural resource base (Ladha et al., 2003). Thus, the region's food safety is vulnerable by the up-andcoming challenges of Post Green Revolution farming, and the expanding population.

Farmers in this region frequently cultivate rice in the kharif (rainy) season, pursued wheat in the rabi season. Rice and wheat crops have complementary edaphic requirements and differing tillage and agronomic practices. For rice, intensive wet tillage (Puddling) is practiced whereas wheat is grown as an irrigated crops. The drastically different seedbed requirements for rice and wheat build troubles in tillage, suitability of 
wheat seeding, upholding of soil structure, and organization of irrigation, weeds and other pests, fertilizers, and crop residue. A little revolve time among rice and wheat is required to prevent delayed wheat planting that can result in yield losses of $35 \mathrm{~kg}$ day $^{-1}$ ha $^{-1}$ (eastern IGP) (Pathak et al., 2003) however, delays do occur because farmers insist on excessive tillage prior to wheat planting and the growing of a medium duration (140 days) basmati rice variety. Timely planting affected by more labour demand in the season. But there is migratory behavior of labour during peak season.

In the IGP, and other parts of Asia, water is progressively more becoming scarce. Per capita availability of water has declined in many Asian countries by $40-60 \%$ between 1955 and 1990 (Cleik, 1993). Agriculture's share of freshwater supplies is likely to decline by $8-10 \%$ because of increasing competition from the urban and industrial sectors (Toung and Bhuiyan, 1994; Sechler et al., 1998). Poor-quality irrigation systems and greater reliance on ground water have led to water table decline of 0.1-1.0 $\mathrm{myr}^{-1}$ in parts of the IGP, resulting is a scarcity and higher cost of pumping water (Gill, 1994; Harrington et al., 1993; Sharma et al., 1994; Sondhi et al., 1994).

The growing labor and water shortages are likely to adversely affect the productivity of the rice-wheat system (Ladha et al., 2003) One way to reduce water demand is to grow direct seeded rice instead of the conventional puddled transplanted rice (Bhuiyan et al., 1995; Caban gon et al., 2002). With consequent aerobic soil conditions, dry seeding of rice avoids water application for puddling and maintaining submerged soil conditions and thus reduces the coverall water demand (Bouman, 2001; Sharma et al., 2002). Another way to save water is to grow rice in raised beds as Borrel et al., (1971) observed that the raised bed system saved 16-43\% water compared with puddled transplanted rice, though at the expense of yield. Similarly, a yield reduction of more than $15 \%$ was reported when rice was grown on raised beds vis-à-vis the puddled transplanted system (Sharma et al., 2003; Vories et al., 2002). Intermittent irrigation and mid-season drying of soil instead of continuous submergence as used in the conventional puddledtransplanted system could be another option for saving water.

Compared with rice, wheat has a much lower water demand. Rice consumes about $80 \%$ of the total water applied in the rice-wheat system. Therefore, much water could be saved if tillage and crop establishment practices of water were adopted in rice. However, the extension of tillage and crop establishment practices followed in wheat to rice without a yield penalty has always been a major challenge for researchers. Minimum tillage or no tillage is becoming an increasingly accepted management technology is parts of the IGP (Hobbs and Gupta, 2002; Singh and Ladha, 2004). Tillage operations performed and establishment methods followed for growing rice should complement those practiced for growing wheat and vice-versa. It is the overall system productivity that should be considered while judging the suitability of a practice and not just the individual crop productivity. The reduced tillage operations with diverse crop establishment methods such as direct seeding on flat land and raised beds can result in significant water savings (Gupta et al., 2003), These practice's effect on yield, soil fertility and water use in the rice- wheat system are not reviewed in a systematic way. The objectives of our study was to evaluate the crop establishment methods and sowing methods on productivity, irrigation requirement and water use efficiency, and net return of the rice-wheat system of the IGP. 


\section{Materials and Methods}

The experiment was conducted at the Research Farm $\left(29^{\circ} \mathrm{N}, 79^{\circ} \mathrm{E}\right.$ altitude and $243.84 \mathrm{~m}$ above mean sea level) of G.B.P.U.A. \& T. Pantnagar, Uttarakhand, India, during 2005-2007. The climate of the area is sub-humid, with an average annual rainfall $1364 \mathrm{~mm} \quad(75-80 \%$ of which is received during July to September), minimum temperature of $0-3.7{ }^{0} \mathrm{C}$ in January, maximum temperature of 37.5 to $38.3{ }^{\circ} \mathrm{C}$ in June and relative humidity of 20 to $62 \%$ throughout the year. The experimental soil $(0-15 \mathrm{~cm})$ was sandy loam in texture, with $\mathrm{pH} 7.8$, organic carbon $0.68 \%$ available nitrogen $263.4 \mathrm{~kg}$ $\mathrm{Nha}^{-1}$, Olsen P $37.8 \mathrm{~kg} \mathrm{ha}^{-1}$ and $1 \mathrm{~N} \mathrm{NH}_{4} \mathrm{OAC}$ extractable K $264.3 \quad \mathrm{~kg} \mathrm{ha}^{-1}$. Sixteen treatments (involving four establishment methods of each for rice and wheat were evaluated in rice-wheat rotation during 200506 and 2006-07 using a strip-strip plot design with 3 replications. In all, there were 12 main plots of $3.6 \mathrm{~m} \times 42.5 \mathrm{~m}$ and 64 sub plots of $3.6 \mathrm{~m} \quad \mathrm{x} 10 \mathrm{~m}$ size each. The rice establishment methods were as direct seeding of dry seed, wet sprouted rice, hand transplanting and machine transplanting. The wheat tillage methods were as conventional sowing of wheat, raised bed planting of wheat strip till drill wheat and zero tillage wheat. Rice (cv. NDR-359) was seeded on June 7 and 3 in direct-seeded plots, whereas transplanting was done on June 28 and 24 in 2005 and 2006, respectively. Rice was seeded in flat beds as well as in raised beds after seed priming (soaking seeds in water for $12 \mathrm{hr}$ followed by air drying). A seeding rate of 40 and $30 \mathrm{~kg} \mathrm{ha}^{-1}$ was used for direct - seeded rice on flat and raised beds, respectively. The wheat variety PBW-343 was sown on 20 and 22 November as per the treatments in 2005 and 2006, respectively.

At maturity, rice and wheat were harvested manually at $15 \mathrm{~cm}$ above ground level. Grain and straw yields were determined from an area of $2 \times 5 \mathrm{~m}^{2}$ in flat beds and $69.7 \mathrm{~m}^{2}$ in center of each plot. The grains were threshed using a plot thresher, dried in a batch grain dryer, and weighed. Grain moisture was determined immediately after weighing. Straw weight was determined after ovendrying at $70{ }^{0} \mathrm{C}$ to constant weight and expressed on an over dry-weight basis.

The cost of cultivation was calculated by taking into account costs of seed, fertilizers, and the wages (Rs.73 day ${ }^{-1}$ ) and machines for land preparation, irrigation, fertilizer application, plant protection, harvesting, and threshing, and the time required per ha to complete an individual field operation. Cost of irrigation was calculated by multiplying time (hr) required to irrigate a particular plot, consumption of diesel by the pump $\left(1 \mathrm{hr}^{-1}\right)$ and cost of diesel. The prices of human and machine labor, and diesel were the prices in north India collected by market survey. Gross income was the minimum support price offered by the Government India for rice and wheat. Net income of the farmers was calculated as the difference between gross income and total cost. System productivity was calculated by adding the grain yield of rice and wheat in each year.

All the data on yield and yield parameters of rice and wheat, water use efficiency, economics, and nutrient uptake were analyzed with IRRISTAT for Windows for one-way analysis of variance (ANOVA) with partitioning of treatments by linear contrast (IRRI, 2005).

\section{Results and Discussion}

\section{Yields}

\section{Rice}

The various rice establishment methods had a non-significant effect on rice yield in both years. During first year due to wheat tillage 
methods had a significant effect on rice yield, but during second year non-significant effect observed. Yields were similar when rice was conventionally transplanted $\left(\mathrm{P}_{3}\right)$, machine transplanted $\left(\mathrm{P}_{4}\right)$, sprouted seeding $\left(\mathrm{P}_{2}\right)$, and direct dry seeding $\left(\mathrm{P}_{1}\right)$ (Table 2). This indicated that puddling of soil, for which normally a large amount of water and labor are required, can be avoided without dry yield penalty in rice. Hand transplanting $\left(\mathrm{P}_{3}\right)$ had a lower yield in 2005 than machine transplanting $\left(\mathrm{P}_{4}\right)$, sprouted rice $\left(\mathrm{P}_{2}\right)$, and direct seeded rice $\left(\mathrm{P}_{1}\right)$. Reducing the number of irrigations in 2006 did not affect the rice yield negatively because adequate precipitation was received. As a result $\mathrm{P}_{3}$ had a yield similar to that of $\mathrm{P}_{1}, \mathrm{P}_{2}$ and $\mathrm{P}_{4}$. Rice direct dry seeded (P1), sprouted seed (P2) or machine transplanting (P4) in 2006 yield $10.27 \%$ to $23.07 \%$ lower than hand transplanting (P3). Partitioning of treatments using linear contrast showed that conventional tillage treatment (T1) gave higher rice yields than the raised bed $\left(\mathrm{T}_{2}\right)$, strip till drill wheat $\left(T_{3}\right)$ and zero tillage $\left(T_{4}\right)$ in 2006, whereas zero tillage treatments $\left(\mathrm{T}_{4}\right)$ gave higher yields than the raised bed $\left(T_{2}\right)$ regardless of seeding method in both the years (Table 2). Transplanted rice on beds apparently suffered form more water stress compared to plot and resulting in lower yields lower grains panicle ${ }^{-1}$ (Table 3) and poor tillering (data not shown or something else) were also recorded in this treatment.

Several researchers have shown that moisture stress at panicle initiation and flowering stages could lead to yield loss because of reduction in number of grains per panicle and spike let sterility (Lu et al., 2001; Nieuwenhuis et al., 2002; Belder et al., 2002). However, despite the higher grains panicle ${ }^{-1}$ (Table 3) in the direct seeded rice (P1) than that of puddle- transplanted conditions ( $\mathrm{P}$ 2, P3 and P4), rice yield were equal in both the year (Table 2). This was due to higher sterility nullifying the advantage of higher grains per panicle in P1. Comparison of transplanting $(\mathrm{P} 3, \mathrm{P} 4)$ and direct seeding (P1, P2) showed that rice yield was higher in the former in 2005.

\section{Wheat}

Rice establishment methods had no effect on wheat yield in 2005 (Table 2). In 2006, however, wheat grown on raised bed (T2) yielded less than in the strip till drill and zero tillage treatment (T3, T4), (Table -2). More over partitioning of treatments using linear contrast showed that in 2006, zero tillage (T4) and strip till drill (T3) gave higher yields than the raised bed (T2) and conventional (T1) treatment. A lower number of effective tillers caused by poor crop establishment as a result of the presence of rice residue caused lower wheat after either puddle-transplanted or direct seeded rice gave equal yields. These findings are in agreement with Ladha et al., (2003) who found that the performance of wheat was not much affected by the way the previous rice crop was grown.

\section{Rice-wheat system}

Treatment effects on rice-wheat (System) yield were observed in both years. (Table 2). The yields of the rice-wheat system were similar in the puddled (P2, P3 and P4) and non-puddled (P1) systems but were lower in direct drill seeded in 2006. Partitioning of treatments by linear contrast showed that system yields under zero tillage (T4), were higher than the strip till drill (T3), bed planting (T2) and conventional planting of wheat (T1) regardless of seeding method moreover, hand transplanting (P3) gave higher system yields than direct drill-seeding (T1) during 2006. The data indicated that there is still a need to improve the direct drillseeded and zero tillage systems to improve productivity. 
Table.1 Description of the treatments

\begin{tabular}{llll}
\hline Treatments & Rice & Treatments & Wheat \\
\hline $\mathbf{P}^{1}$ & Direct seeded rice & $\mathbf{T}^{1}$ & Conventional wheat \\
$\mathbf{P}^{\mathbf{2}}$ & Wet Sprouted rice & $\mathbf{T}^{\mathbf{2}}$ & Bed planting \\
$\mathbf{P}^{\mathbf{3}}$ & Hand transplanting & $\mathbf{T}^{\mathbf{3}}$ & Strip-till drill \\
$\mathbf{P}^{\mathbf{4}}$ & Machine transplanting & $\mathbf{T}^{\mathbf{4}}$ & Zero-till drill \\
\hline
\end{tabular}

Table.2 Effect of crop establishment methods on yields of rice and wheat

\begin{tabular}{ccccccc}
\hline Treatment & \multicolumn{6}{c}{ Grain Yield $\left(\mathbf{M g ~ h}^{-\mathbf{1}}\right)$} \\
\cline { 2 - 7 } & \multicolumn{2}{c}{ Rice } & \multicolumn{2}{c}{ Wheat } & \multicolumn{2}{c}{ System } \\
\cline { 2 - 7 } & $\mathbf{2 0 0 5}$ & $\mathbf{2 0 0 6}$ & $\mathbf{2 0 0 5}$ & $\mathbf{2 0 0 6}$ & $\mathbf{2 0 0 5}$ & $\mathbf{2 0 0 6}$ \\
\hline $\mathbf{P}^{\mathbf{1}}$ & 4.3 & 3.0 & 3.5 & 5.2 & 7.8 & 8.2 \\
$\mathbf{P}^{\mathbf{2}}$ & 4.1 & 3.2 & 3.6 & 5.2 & 7.7 & 8.4 \\
$\mathbf{P}^{\mathbf{3}}$ & 3.7 & 3.9 & 3.5 & 4.9 & 7.2 & 8.8 \\
$\mathbf{P}^{\mathbf{4}}$ & 3.9 & 3.5 & 3.5 & 4.4 & 7.4 & 7.9 \\
$\mathbf{C D}$ & $\mathrm{NS}$ & $\mathrm{NS}$ & $\mathrm{NS}$ & 0.5 & - & - \\
$\mathbf{T}^{\mathbf{1}}$ & 4.0 & 3.7 & 3.2 & 4.3 & 7.2 & 8.0 \\
$\mathbf{T}^{\mathbf{2}}$ & 3.6 & 3.3 & 3.0 & 4.8 & 6.6 & 7.1 \\
$\mathbf{T}^{\mathbf{3}}$ & 4.1 & 3.2 & 3.4 & 4.9 & 7.5 & 8.1 \\
$\mathbf{T}^{\mathbf{4}}$ & 4.4 & 3.4 & 4.6 & 5.7 & 9.0 & 9.1 \\
$\mathbf{C D}$ & 0.4 & $\mathrm{NS}$ & 0.5 & 0.2 & - & - \\
\hline
\end{tabular}

Table.3 Effect of crop establishment methods on yield attributes of rice crop

\begin{tabular}{|c|c|c|c|c|c|c|c|c|}
\hline \multirow[t]{2}{*}{ Treatments } & \multicolumn{2}{|c|}{ Tiller $\mathrm{m}^{-2}$} & \multicolumn{2}{|c|}{ Panicle length $(\mathrm{cm})$} & \multicolumn{2}{|c|}{ Grains/panicle } & \multicolumn{2}{|c|}{ 1000-grain wt.(g) } \\
\hline & $2005-06$ & $2006-07$ & $2005-06$ & $2006-07$ & $2005-06$ & $2006-07$ & $2005-06$ & 2006-07 \\
\hline \multicolumn{9}{|l|}{ Rice } \\
\hline $\mathbf{P}$ & 245 & 270 & 26.2 & 24.4 & 135.5 & 103.9 & 28.1 & 27.5 \\
\hline $\mathbf{P}$ & 231 & 213 & 25.3 & 24.1 & 132.2 & 103.4 & 27.9 & 27.3 \\
\hline $\mathbf{P}$ & 225 & 212 & 24.7 & 23.9 & 131.6 & 98.5 & 26.5 & 27.1 \\
\hline $\mathbf{P}$ & 206 & 200 & 24.0 & 23.2 & 119.4 & 91.0 & 26.4 & 26.9 \\
\hline S.Em \pm & 11 & 15.4 & 0.4 & 1.1 & 5.0 & 6.3 & 0.3 & 0.5 \\
\hline C.D. $(5 \%)$ & NS & NS & 1.3 & NS & NS & NS & 1.1 & NS \\
\hline \multicolumn{9}{|l|}{ Wheat } \\
\hline $\bar{T}$ & 219 & 217 & 24.7 & 23.8 & 128.8 & 97.8 & 27.0 & 26.9 \\
\hline $\mathbf{T}$ & 212 & 213 & 24.4 & 23.7 & 125.9 & 86.1 & 26.5 & 26.8 \\
\hline $\mathbf{T}$ & 234 & 226 & 24.9 & 24.1 & 130.2 & 105.6 & 27.6 & 27.3 \\
\hline $\mathbf{T}$ & 243 & 229 & 26.1 & 24.3 & 133.5 & 107.3 & 28.0 & 27.7 \\
\hline S.Em \pm & 8.7 & 18.6 & 0.52 & 1.1 & 4.3 & 4.2 & 0.4 & 0.3 \\
\hline C.D. $(5 \%)$ & NS & NS & NS & NS & NS & 14.5 & NS & NS \\
\hline
\end{tabular}


Table.4 Effect of crop establishment methods on yield attributes of wheat crop

\begin{tabular}{|c|c|c|c|c|c|c|c|c|}
\hline \multirow[t]{2}{*}{ Treatments } & \multicolumn{2}{|c|}{ Tiller $\mathrm{m}^{-2}$} & \multicolumn{2}{|c|}{$\begin{array}{l}\text { Spike length } \\
(\mathrm{cm})\end{array}$} & \multicolumn{2}{|c|}{ grains/spike } & \multicolumn{2}{|c|}{ 1000-grain wt.(g) } \\
\hline & $2005-06$ & $2006-07$ & $\begin{array}{c}2005- \\
06\end{array}$ & $\begin{array}{c}2006- \\
07\end{array}$ & $2005-06$ & $2006-07$ & $\begin{array}{r}2005 \\
06\end{array}$ & $2006-07$ \\
\hline \multicolumn{9}{|l|}{ Rice } \\
\hline $\mathbf{P}^{1}$ & 432 & 426 & 8.6 & 9.8 & 49.9 & 52.2 & 43.0 & 43.6 \\
\hline $\mathbf{P}^{2}$ & 417 & 416 & 8.5 & 9.6 & 49.3 & 51.1 & 40.5 & 42.5 \\
\hline $\mathbf{P}^{3}$ & 412 & 407 & 8.4 & 9.6 & 47.3 & 50.2 & 39.9 & 41.6 \\
\hline $\mathbf{P}^{4}$ & 385 & 400 & 8.3 & 9.2 & 45.6 & 49.6 & 38.8 & 41.2 \\
\hline S.Em \pm & 41 & 24 & 0.26 & 0.04 & 1.32 & 0.40 & 1.8 & 0.3 \\
\hline C.D. (5\%) & NS & NS & NS & 0.15 & NS & 1.4 & NS & 0.9 \\
\hline \multicolumn{9}{|l|}{ Wheat } \\
\hline$T^{1}$ & 401 & 397 & 8.67 & 9.3 & 47.3 & 50.4 & 40.5 & 39.8 \\
\hline$T^{2}$ & 393 & 389 & 8.28 & 9.0 & 45.9 & 49.3 & 39.4 & 41.6 \\
\hline $\mathbf{T}^{3}$ & 402 & 418 & 8.71 & 9.6 & 49.4 & 51.5 & 40.6 & 42.7 \\
\hline$T^{4}$ & 450 & 445 & 8.73 & 10.1 & 49.9 & 51.9 & 41.6 & 45.0 \\
\hline S.Em \pm & 18 & 29 & 0.20 & 0.13 & 1.40 & 0.84 & 1.3 & 0.5 \\
\hline C.D. $(5 \%)$ & NS & NS & NS & 0.45 & NS & NS & NS & 1.6 \\
\hline
\end{tabular}

Table.5 Effect of crop establishment methods on energy use $\left(\mathrm{GJha}^{-1}\right)$ in rice, wheat and ricewheat cropping system (total)

\begin{tabular}{|l|c|c|c|c|c|c|c|}
\hline \multicolumn{2}{|l|}{ Treatments } & \multicolumn{3}{|c|}{$2005-06$} & \multicolumn{3}{c|}{$2006-07$} \\
\hline Rice & Wheat & Rice & Wheat & Total & Rice & Wheat & Total \\
\hline \multirow{4}{*}{ DSR } & CW & 11.15 & 10.52 & 21.67 & 10.16 & 11.14 & 21.3 \\
\cline { 2 - 8 } & BPW & & 10.27 & 21.42 & & 11.29 & 21.45 \\
\cline { 2 - 8 } & STW & & 8.19 & 19.34 & & 8.38 & 18.54 \\
\cline { 2 - 8 } & ZTW & & 8.25 & 19.40 & & 8.59 & 18.75 \\
\cline { 2 - 8 } & Mean & 11.15 & 9.31 & 20.46 & 10.16 & 9.85 & 20.01 \\
\hline \multirow{4}{*}{ SR } & CW & 11.59 & 10.38 & 21.97 & 10.59 & 10.91 & 21.50 \\
\cline { 2 - 8 } & BPW & & 10.21 & 21.80 & & 10.77 & 21.36 \\
\cline { 2 - 8 } & STW & & 8.11 & 19.70 & & 8.50 & 19.09 \\
\cline { 2 - 8 } & ZTW & & 8.25 & 19.81 & & 8.77 & 19.36 \\
\cline { 2 - 8 } & Mean & 11.59 & 9.24 & 20.83 & 10.59 & 9.74 & 20.33 \\
\hline \multirow{6}{*}{ HT } & CW & 13.22 & 11.13 & 24.35 & 11.86 & 11.81 & 23.67 \\
\cline { 2 - 8 } & BPW & & 10.99 & 24.21 & & 11.54 & 23.40 \\
\cline { 2 - 8 } & STW & & 7.99 & 21.21 & & 8.19 & 20.05 \\
\cline { 2 - 8 } & ZTW & & 8.09 & 21.31 & & 8.30 & 20.16 \\
\cline { 2 - 8 } & Mean & 13.22 & 9.55 & 22.77 & 11.86 & 9.96 & 21.82 \\
\hline MT & CW & 12.49 & 10.92 & 23.41 & 11.68 & 11.76 & 23.44 \\
\cline { 2 - 8 } & BPW & & 10.94 & 23.43 & & 10.83 & 22.51 \\
\cline { 2 - 8 } & STW & & 8.03 & 20.52 & & 8.34 & 20.02 \\
\cline { 2 - 8 } & ZTW & & 8.05 & 20.54 & & 8.36 & 20.04 \\
\cline { 2 - 8 } & Mean & 12.49 & 9.49 & 21.98 & 11.68 & 9.82 & 21.50 \\
\hline
\end{tabular}


Table.6 Effect of establishment methods on net returns (Rs) from rice-wheat system

\begin{tabular}{|c|c|c|c|}
\hline \multicolumn{2}{|l|}{ Treatments } & \multirow[t]{2}{*}{2005} & \multirow[t]{2}{*}{2006} \\
\hline Rice & Wheat & & \\
\hline \multirow[t]{5}{*}{$\overline{\text { DSR }}$} & $\mathrm{CW}$ & 41173 & 45147 \\
\hline & BPW & 40497 & 48085 \\
\hline & STW & 45712 & 51377 \\
\hline & ZTW & 55720 & 57345 \\
\hline & Mean & 45775.5 & $\begin{array}{l}50488.5 \\
\end{array}$ \\
\hline \multirow[t]{5}{*}{ SR } & CW & 35744 & 39166 \\
\hline & BPW & 34985 & 44559 \\
\hline & STW & 46100 & 46105 \\
\hline & ZTW & 52474 & 57060 \\
\hline & Mean & 42325.75 & 46722.5 \\
\hline \multirow[t]{5}{*}{ HT } & $\mathrm{CW}$ & 31420 & 39238 \\
\hline & BPW & 28607 & 42800 \\
\hline & STW & 35145 & 35504 \\
\hline & ZTW & 55189 & 57376 \\
\hline & Mean & 37590.25 & 43729.5 \\
\hline \multirow[t]{5}{*}{ MT } & $\mathrm{CW}$ & 45346 & 34554 \\
\hline & BPW & 41021 & 37587 \\
\hline & STW & 48341 & 42553 \\
\hline & ZTW & 56818 & 48799 \\
\hline & Mean & 47881.5 & 40873.25 \\
\hline
\end{tabular}

\section{Energy input}

Hand transplanting rice had the highest energy input requirement (13.22 $\left.\mathrm{GJha}^{-1}\right)$ followed by machine transplanting rice (12.49 $\mathrm{GJh}^{-1}$ ) (Table-6). Direct seeded rice had the lowest energy input requirements. Conventionally tilled wheat had the highest energy requirement, whereas all other treatments had a lower energy input requirement. Direct seeded rice-strip till drill wheat had lower energy input requirement (19.34 and 18.54 GJha-1, respectively) compared to the other treatment combination, because of the larger human labor requirement for transplanting rice (Table 5).

\section{Economic analysis}

The net returns of rice were higher in first year than in second year largely because of more rainfall resulting in a lower cost of irrigation. The largest financial benefit was for hand transplanting rice (P4) followed by direct seeding. In wheat returns were higher in second year than in first year largely because of the differences in the amount of water applied. On a system basis, the returns were higher in direct seeded rice-zero tillage wheat in first year and in hand transplantingzero tillage wheat in second year (Table 6).

Conventional practices of puddle transplanting in rice and conventional tillage in wheat require a large amount of energy input. The emerging shortages and increasing costs of water and labor will therefore force and changes in the way farmers grow these crops.

An extended turnaround time between rice and wheat, delays wheat planting that can result in yield losses. No tillage can allow timely seeding of wheat immediately after rice harvest. This would also enable farmers to delay rice seeding until end of June when the monsoon season starts, therefore reducing the irrigation applications in rice planting. But 
there in grower apprehension that planting of rice in May will results in more yield compared to planting in July.

The second year results showed that zero tillage and direct seeding methods require the less energy and gave the higher net return than the conventional method of planting. The water saving feature of direct seeding is largely attributed to the avoidance of puddling used in transplanted rice. However, saving in irrigation largely depend on the occurrence and distribution of rainfall during the crop growing period. Therefore, more efforts will be needed to evaluate and improve the technologies on a site and season-specific basis. Shifting from conventional tillage practice to zero tillage system may cause change in soil properties, micro flora, micro fauna and weed flora affecting long-term crop productivity and input use efficiency. Therefore, long-term changes in the crop performance, input efficiencies, and weed flora should be monitored to achieve a paradigm shift in farmers' practices. Appropriate integration of crop residues in zero tillage rice-wheat system is another crucial issue, which needs to be addressed. Therefore, there is need to develop cost effective and profitable residue management practices, which will attract the farmers for adoption. It is also important that small-scale farmers trained and have access to these technologies.

\section{References}

Belder, P., B.A.M. Bouman, L. Spiertz, Guoan Lu, and E.J.P. Quilang. 2002. Water use of alternately submerged and non-submerged irrigated lowland rice. 51-61. In B.A.M. Bouman et al., (eds.) Water-wise rice production. International Rice Research Institute, Los Banos, Philippines.

Bhuiyan, S.I., M.A. Sattar, and M.A.K. Khan.
1995. Improving water use efficiency in rice irrigation through wet seeding. Irrigation Sci. 16:1-8.

Borrel, A.K., A.L. Garside, and S. Fukai. 1997. Improving efficiency of water for irrigated rice in semi-arid tropical environment. Field Crops Res. 52:231248

Bouman, B.A.M., 2001. Coping with the water crisis: water management strategies in rice produion. Paper presented at the International Symposium on Sustainable soil and Water Resources Management, 30-31 May 001, Diliman, Ouezon City, Philippines.

Cabangon, R.J., T.P. Tuong and N.B. Abdullah. 2002. Comparing water input and water use efficiency of transplanted and direct-seeded rice production systems. Agric. Water Manage 57: 11-3.

Dawe, D., S. Frolking, and C. Li, 2004. Trends in rice-wheat area in China. Field Crops Res. 87: 89-95.

Gill, K.S., 1994. Sustainability issues related to rice-wheat production system. P, 3061 In R.S. Paroda et al., (eds.) Sustainability of rice-wheat production system in Asia. FAO, Bangkok (Thailand).

Gleik, P.H., (ed.) 1993. Water crisis: a guide to the world fresh water resources. 473 $\mathrm{p}$ Pacific Institute for Studies in Development, Environment and Security Stockholm Environment Institute. Oxford University Press, New York.

Gupta, R.K., P.R. Hobbs, J. Jiaguo, and J.K. Ladha. 2003. Sustainability of postGreen revolution agriculture. 1-25. In J.K. Ladha et al., (eds.) Improving the productivity and sustainability of ricewheat systems: issues and impacts. ASA special Publication No. 65. Madison, Wis., USA.

Harrington, L.W., S. Fujisaka, M.L. Morris, 
P.R. Hobbs, H.C. Sharma, R.P. Singh, M.K. Choudhary, and S.D. Dhiman. 1993. Wheat and rice in karnal and Kurukshetra districts, Haryana, India: farmers' practices, problems and an agenda for action. ICAR, HAU, CIMMYT, Mexico, and IRRI, Los Banos, Philippines.

Hobbs, P.R., and R.K. Gupta. 2002. Ricewheat cropping systems in the IndoGengetic plains: issues of water productivity in resource-conserving technologies. Water Productivity Workshop, 12-14 November 2001, International Water Management Institute, Sri Lanka.

Ladha, J.K., H. Pathak, A.T. Padre, D. Dawe, and R.K. Gupta. 2003. Productivity trends in intensive rice-wheat cropping system in Asia. 45-76. In J.K. Ladha et al., (eds.) Improving the productivity and sustainability of rice-wheat system: issues and impacts. ASA Special Publication No. 65. Madison. Wis. USA.

Ladha, J.K., K.S. Fischer, M. Hossain, P.R. Hobbs, and B. Hardy. 2000. Improving the productivity of rice-wheat systems of the Indo Gangetic Plains: a synthesis of NARS-IRRI partnership research. IRRI Discussion Paper No. 40. International Rice Research Institute, Los Banos, Philippines.

Lu-Jun, Hirasawa-T, and Lu-J. 2001. Study on intermittent irrigation for paddy rice: I. Water use efficiency. Pedosphere 11:49-56

Nieuwenhuis, J., B.A.M. Bouman, and A. Castaneda. 2002. Crop-water responses of aerobically grown rice: preliminary results of pot experiments. P. 177-185. In B.A.M. Bouman et al., (eds.) Waterwise rice production. International Rice Research Institute, Los Banos, Philippines.

Pathak, H., J.K. Ladha, P.K. Aggarwal, S.
Peng, S. Das, Y. Singh, Bijay-Singh, S.K. Kamra, B. Mishra, A.S.R.A.S. Sastri, H.P. Aggarwal, D.K. Das, and R.K. Gupta. 2003. Trends of climatic potential and on-farm yields of rice and wheat in the Indo-Gangetic Plains. Field Crops Res. 80:223-234.

Seckler, D., U. Amarasinghe, D. Molden, R. De Silva, and R. Barker. 1998. World water demand and supply, 1990 to 2025: scenarios and issues. Research Report 19. International Water Management Institute. Colombo, Sri Lanka.

Sharma, H.C., S.D. Dhiman, and V.P. Singh. 1994. Reice-wheat cropping system in Haryana: potential, possibilities and limitations. P. 27-39. In S.D. Dhiman et al., (eds.) Proceedings of the symposium on sustainability of ricewheat system in India. CCS Haryana Agricultural University, Regional Research Station, Karnal, India.

Sharma, P.K., J.K. Ladha, and Lav Bhushan. 2003. Soil physical effects of pudding in rice-wheat cropping system. P. 97114. In J.K. Ladha et al., (eds.) Improving the productivity and sustainability of rice-wheat system: issues and impact. ASA Special Publication no. 65. ASA Madison, Wis.

Sharma, P.K., L. Bhushan, J.K. Landha, R.K. Naresh, R.K. Gupta, V. Balasubramanian, and B.A.M. Bouman. 2002. Crop-water relations in ricewheat cropping systems and water management practices in a marginally sodic, medium-textured soil. p. 223235. In B.A.M. Bouman et al., (eds.) Water-wise rice production. International Rice Research Institute, Los Banos, Philippines.

Singh, Y., and J.K. Ladha. 2004. Principles and practices of no-tillage systems in rice-wheat systems of Indo-Gangetic plains. p. 167-207. In R. Lal et al., 
(eds.) Sustainable Agriculture and the rice-wheat systems. Mercel Dekker Inc., New York, USA.

Sondhi, S.K., M.P. Kaushal, and P.Singh. 1994. Irrigation management strategies for rice-wheat cropping system. p. 95104. In S.D. Dhiman et al., (eds.) Proceedings of the symposium on sustainability of rice-what system in India. CCS Haryana Agricultural University, Regional Research Station,
Karnal, India.

Toung, T.P., and S.I. Bhuiyan. 1994. Innovations toward improving wateruse efficiency in rice. Paper presented at the Word Bank's 1994 Water Resource Seminar, 13-15 December 1994. Virginia, USA.

Vories, E.D., P.A. Counce, and T.C. Keilsling. 2002. Comparison of flooded and furrow irrigated rice on clay. Irrig. Sci. 21: 139-144.

\section{How to cite this article:}

Shweta, Manu Malik, S.K. Saini and Bhardwaj, A.K. 2017. Variation in Productivity and Energy Use in Rice-Wheat System under Different Establishment Methods. Int.J.Curr.Microbiol.App.Sci. 6(9): 2794-2803. doi: https://doi.org/10.20546/ijcmas.2017.609.344 